\title{
Communicative Properties of the Manager's Personality and Managerial Decision-making
}

\author{
Natalya Matyash ${ }^{1}$, Tatyana Pavlova ${ }^{1}$, Ekaterina Chukhacheva ${ }^{1}$ \\ ${ }^{1}$ Bryansk State University named after academician I.G. Petrovsky, Bryansk, Russia \\ *Email: vds24@yandex.ru
}

\begin{abstract}
The article is devoted to studying the relationship between the communicative properties of the manager personality and managerial decision-making styles. This problem is essential and relevant since the communicative properties of the manager's personality are rarely considered when making managerial decisions. Research has shown that most managers have developed communicative qualities and constructive decision-making styles. As a result of the correlation analysis of the data, significant correlations were revealed (at the level of 0.05) between hyperactivity as a decision-making style and indicators of self-control in communication (positive relationship) and indicators of organisational skills (negative relationship). Factor analysis of the data obtained showed that the communicative properties of a person could be combined with hyper-vigilance as a decision-making style, forming the factors "selfcontrol" and "impulsive sociability".
\end{abstract}

Keywords: Manager, Communicative properties of the manager's personality, Managerial decision-making

\section{INTRODUCTION}

Modern research in the field of management psychology, organisational and economic psychology, labour psychology shows that the head of any level, from a small department to a corporation, is one of the central figures in ensuring the effective and productive activities of the organisation.

Communication is defined as a semantic aspect of social interaction [1], manifests itself in a person's social activity, the success of which largely depends on the formation of the communicative properties of the individual. The communicative properties of a person are usually defined as stable characteristics of human behaviour in communication, significant for his social environment.

In psychology, the concept of "communicative competence" is also widespread, defined as the ability to interact with others effectively, establish and maintain the necessary effective contacts with other people $[2,3$, 4], which emphasises the importance of communicative personality traits.

Communication is vital for a manager. $[2,5,6]$ Since business communication is one of the fundamental aspects of managerial activity, it is one of its specific features; the expressed communicative qualities of a person are necessary for the manager to implement all managerial functions effectively.

The problem of managerial decisions is also highly relevant in modern psychology engaged in the study of managerial activity and the personality of the head [7]. Decision-making in management activities is one of the main stages of the management process. A managerial decision is the main result of managerial activity, the product of managerial labour.

Decision-making is defined as a choice by a person or a group of people in an uncertain situation between alternative options, available objects, ideas and actions.

Considering the decision-making process in the context of will and deliberate action, L.S. Vygotsky and S.L. Rubinstein focused on the struggle of motives when making a decision. "The battle between motives often occurs long before the actual situation in which we need to act is in front of us... The decision is made, and the struggle often ends long before the real or actual struggle has begun," L.S. Vygotsky noted [8, thereby emphasising the extreme importance of the stage of direct decision-making. S.L. Rubinstein also pointed out that the decision acts as a particular deliberate action in cases where there is a complex struggle of motives or the necessary action is delayed [9]. 
According to B.F. Lomov, decision-making permeates all activity components, represents the main link in its structure, and is included in all the level characteristics of the process of its organisation. Therefore, when studying the components of activity, it is essential to consider the components of the decisionmaking process [10].

Modern psychological research has revealed that the decision-making process of a manager is determined by many psychological factors and personal manifestations, such as creativity, gender characteristics [11, 12], personality orientation and its value orientations [13, 14], features of self-awareness and self-esteem, rationality, locus of control, personal readiness for risk [15], etc. However, the nature of the influence of the communicative properties of the personality of the head on managerial decision-making has been insufficiently studied. In contrast, the need for the development of the communicative properties of the head, required during business communication, permeating all aspects of managerial activity, is recognised obviously.

\section{RESEARCH METHODS}

To study the correlation of the communicative properties of the personality of a manager and managerial decision-making, we used the following methods during an empirical study:

1. Test of communication skills by L. Mikhelson (in the adaptation by Yu.Z. Gilbukh). The methodology has the following scales: Dependent way of communication; Competent way of communication; Aggressive way of communication.

2. The test "Assessment of self-control in communication" by M. Snyder.

3. Questionnaire "Communicative and Organisational skills (COS)" by V.V. Sinyavsky, V.A. Fedorshin, includes two scales: Organisational skills; Communicative skills.

4. Questionnaire "Communicative competence" (according to R.I. Mokshantsev).

5. Melbourne Decision Making Questionnaire (MDMQ) (L. Mann, P. Burnett, M. Radford, S. Ford) in the adaptation of T. V. Kornilova. It has the following scales: Vigilance; Back-Passing; Procrastination, Hypervigilance.

Statistical analysis of the data was carried out using the K. Pearson's linear correlation coefficient, factor analysis, using the IBM SPSS Statistics 21.0 software.

The study involved middle managers of organisations in Bryansk (Russia) $(\mathrm{N}=21)$ aged 24 to 36 years.

\section{RESEARCH RESULTS}

To identify the communicative properties of the manager's personality, the method "Test of communicative skills" was carried out by L. Michelson in the adaptation by Yu.Z. Gilbukh. It was revealed that most managers have a competent type of communication $(95.24 \%), 4.76 \%$ of the entire group have a dependent type of communication, and the aggressive type of communication was not manifested in the subjects. Consequently, it can be noted that middle managers are quite competent in communicating with others.

Next, the method "Assessment of self-control in communication" by M. Snyder was applied. In general, the following data were obtained for the group: $71.43 \%$ of the subjects in our sample have a high level of communicative self-control in communication, $23.81 \%$ have an average level of communicative self-control, and only $4.76 \%$ of managers have a low level of communicative self-control.

The results obtained using the methodology "Communicative and organisational skills" (V.V. Sinyavsky, V.A. Fedoroshin) show that most managers $(47.62 \%)$ have a high level of communicative skills, $14.28 \%$ found the highest level of manifestation of communicative skills, and $38.1 \%$ of the subjects have an average level of expression of communicative skills. Low and very low levels of communicative skills in the group were not revealed. This technique revealed organisational skills in managers at a high and medium level equally (50\% of the subjects each). The highest level of organisational skills and low and very low levels in the group of managers were not found.

Using the "Communicative Competence" methodology, it was found that $66.67 \%$ of managers have an average level, and $33.33 \%$ have a high level.

Exciting results of interrelations of indicators of communicative personality traits were obtained using correlation analysis (K. Pearson's linear correlation coefficient). Thus, the competent type of communication, according to L. Mikhelson, has a significant negative correlation with dependent (0.4047 , correlation is significant at 0.05 ) and aggressive $(-0.5446$, correlation is significant at 0.01$)$ types of communication. Consequently, these types of communication practically do not intersect, and the presence of a competent type of communication in the manager seems to suppress the manifestations of dependent and aggressive types of communication.

To identify the individual decision-making style of managers, the Melbourne Decision-making Questionnaire was used; the results show that the most pronounced decision-making style is "vigilance", found in $76.19 \%$ of the subjects. This means that when making 
decisions, alternatives are considered, the risk is excluded. The "back-passing" style was found in $14.28 \%$ of the sample members, the "procrastination" and "hyper-vigilance" styles accounted for $4.76 \%$ of the subjects, respectively.

Correlation analysis of correlations on the scales of the questionnaire showed that "vigilance" and "procrastination" have a significant negative correlation $(-0.5128$, the correlation is significant at 0.01). In addition, there are substantial correlations between the indicators of "back-passing" and "procrastination" (0.5273, the correlation is significant at 0.01$)$, as well as "back-passing" and "hyper-vigilance" (0.5156, the correlation is significant at 0.01). Consequently, it can be noted that non-constructive coping in decisionmaking can interact and support each other, possibly contributing to the manifestation of irrational decisionmaking styles.

\section{RESULTS DISCUSSION}

The data obtained during the study show that the communicative properties of managers' personalities, identified using the selected techniques, are formed at high and medium levels. Managers are characterised by a competent type of communication, a high level of communicative self-control in communication, a high level of communicative skills and a relatively high level of organisational skills; managers demonstrate communicative competence. It can be assumed that such indicators are due to the need for constant business communication of middle managers, both with superiors and subordinates, which is why these qualities are constantly being improved.

In addition, the results show that the competent type of communication manifests itself separately from the aggressive and dependent types of communication.
The data obtained on decision-making styles indicate that the prevailing decision-making style among the testees is "vigilance", for the managers of our sample, when making decisions, it is characteristic of clarifying goals and objectives, considering alternatives and opportunities. I.e., most of the testees make constructive and balanced decisions, while procrastination, delay in decision-making and impulsive decision-making are entirely out of their character.

It was also revealed that inefficient decision-making styles could overlap with each other.

To identify the interrelationships of the communicative properties of managers' personalities and managerial decision-making styles, we conducted a correlation analysis of the data obtained by all the methods carried out.

The data obtained in the study are presented in the table (Table 1).

A significant correlation was revealed between selfcontrol indicators in communication and hypervigilance as a decision-making style $(0.4814$, the correlation is significant at the level of 0.05$)$. Therefore, excessive self-control during communication can lead to extreme caution when making decisions. In addition, there was also a significant negative correlation between hyperactivity and indicators of organisational skills. It can be assumed that the successful performance of organisational functions of managerial activity makes it necessary to suppress excessive caution when making decisions, since often their implementation largely depends on subordinate performers and not on the person making the decision, and also makes it necessary to delegate authority.

To clarify the correlation between the properties of the communicative sphere of the manager's personality, their managerial decision-making styles, and their latent

Table 1. Matrix of correlations between the communicative properties of personality and decision-making styles

\begin{tabular}{|c|c|c|c|c|c|c|c|}
\hline & $\begin{array}{c}\text { Dependent } \\
\text { type of } \\
\text { communicatio } \\
n\end{array}$ & \begin{tabular}{|} 
Competent \\
type of \\
communicatio \\
$n$
\end{tabular} & $\begin{array}{c}\text { Aggressive } \\
\text { type of } \\
\text { communicatio } \\
n\end{array}$ & $\begin{array}{c}\text { Self-control in } \\
\text { communicatio } \\
n\end{array}$ & $\begin{array}{c}\text { Organisationa } \\
\text { I skills }\end{array}$ & $\begin{array}{c}\text { Communicati } \\
\text { ve skills }\end{array}$ & $\begin{array}{c}\text { Communicative } \\
\text { competence }\end{array}$ \\
\hline Vigilance & 0,0633 & $-0,0007$ & $-0,0573$ & 0,1267 & 0,103654 & 0,2656 & 0,0371 \\
\hline Back-passing & $-0,1827$ & 0,0971 & 0,0783 & 0,2435 & $-0,25541$ & $-0,093$ & $-0,1301$ \\
\hline Procrastination & $-0,2069$ & 0,2081 & $-0,0013$ & 0,1744 & $-0,08046$ & $-0,1199$ & $-0,1568$ \\
\hline Hyper-vigilance & $-0,2723$ & 0,2139 & 0,0532 & 0,4814 & $-0,45668$ & 0,1896 & $-0,0716$ \\
\hline
\end{tabular}


structure, we conducted a factor analysis of the data obtained using the IBM SPSS Statistics 21.0 software. All the studied indicators were included in the number of analysed variables. The results are presented in Table 2 .

Five significant factors were identified that explain $79.304 \%$ of the variance of the results.

Factor 1 is basically represented by indicators of non-constructive decision-making styles: "procrastination", "back-passing", and "hypervigilance".

The previous correlation analysis found significant correlations between these indicators. The ratio of these indicators to a single factor allows us to consider this combination as a manifestation of managers' general lack of constructiveness in decision-making. Indicators of the communicative sphere do not play a significant role in the content of this factor.

The most significant weight in this factor $(0.811)$ has the indicator "procrastination", the value of "backpassing" (0.715), which has a similar effect, is also significant, which allows us to call this factor "protective back-passing".

Factor 2 includes the variable "self-control in communication" by the most significant weight (0.903); in addition to it, "hyper-vigilance" has a considerable weight (0.449); in general, this factor is called "selfcontrol".

Factor 3 combined two variables: "communicative skills" (0.758) and "hyper-vigilance" (0.547), received the name "impulsive sociability".

Factor 4 includes the indicator "aggressive type of communication" $(0,656)$; we can also mention the variables "communicative competence" $(0,302)$ and "self-control in communication" $(0,261)$; other variables are less pronounced. In general, this factor is called "assertiveness".

Factor 5 by a considerable margin includes the variable "competent type of communication" $(0,656)$, which gave the name to this factor.

Thus, among the data obtained, we identified latent factors that received the names "defensive backpassing", "self-control", "impulsive sociability", "assertiveness", and "competent type of communication". One of these factors - "defensive back-passing" combines ineffective decision-making styles, two factors - "assertiveness" and "competent type of communication" - relate to the communicative properties of the individual, and two more factors "self-control" and "impulsive sociability" - are a combination of the communicative properties of the individual and the style of "hyper-vigilance" in decision-making. Consequently, it can be noted that the communicative properties of the manager's personality play an essential role in the manifestation of the "hypervigilance" style.

\section{CONCLUSIONS}

The data and results obtained during the study allow us to conclude that young middle managers have wellformed communicative properties, among which the

Table 2. Matrix of rotated components

\begin{tabular}{|l|c|c|c|c|c|}
\hline & 1 & 2 & 3 & 4 & 5 \\
\hline $\begin{array}{l}\text { Dependent type of } \\
\text { communication }\end{array}$ &,- 117 &,- 084 &,- 088 &,- 943 &,- 159 \\
\hline $\begin{array}{l}\text { Competent type of } \\
\text { communication }\end{array}$ &, 087 &, 190 &, 036 &, 226 &, 938 \\
\hline $\begin{array}{l}\text { Aggressive type of } \\
\text { communication }\end{array}$ &, 028 &,- 097 &, 047 &, 656 &,- 714 \\
\hline Self-control in communication &, 008 &, 903 &, 006 &, 261 &, 061 \\
\hline Organisational skills &,- 196 &,- 053 &,- 857 &, 061 &, 105 \\
\hline Communicative skills &,- 337 &,- 071 &, 758 &, 131 &, 154 \\
\hline Communicative competence &,- 065 &,- 711 &,- 041 &, 302 &,- 239 \\
\hline Vigilance &,- 810 &, 218 &, 098 &, 050 &, 003 \\
\hline Back-passing &, 715 &, 308 &, 217 &, 094 &,- 089 \\
\hline Procrastination &, 811 &, 126 &, 000 &, 124 &, 160 \\
\hline Hyper-vigilance &, 353 &, 449 &, 547 &, 240 &, 010 \\
\hline
\end{tabular}

Notes: Extraction method: Principal Component analysis; Rotation method: Varimax with Kaiser normalisation. 
competent type of communication and self-control in communication stand out.

The characteristics of the decision-making style are also positive; the effective decision-making style "vigilance" prevails.

Correlation analysis of the data obtained showed the presence of significant correlations (at the level of 0.05) between the decision-making style "hyper-vigilance" and self-control in communication (positive relationship) and organisational skills (negative relationship). It can be assumed that high rates of hypervigilance and self-control in communication reinforce each other, and organisational activity reduces the manifestations of prudence in decision-making.

Factor analysis of the results revealed five significant factors: "defensive back-passing", "selfcontrol", "impulsive sociability", "assertiveness", and "competent type of communication". Two of these factors, "self-control" and "impulsive sociability", combine the communicative properties of personality and hyper-vigilance in decision-making; i.e., the communicative properties of personality can be combined with one of the managers' decision-making styles.

\section{REFERENCES}

[1] A.A. Bodalev, Personality and Communication [Lichnost' i obshchenie], International Pedagogical Academy [Mezhdunarodnaya pedagogicheskaya akademiya], 1995, $324 \mathrm{p}$.

[2] J.M. Šafránková, M.Šikýř, Current Trends and Challenges of Modern Management and Human Resource Development, Prague y Czech Technical University in Prague, 2014, 100 p.

[3] Y.M. Zhukov, Communicative training [Kommunikativnyj trening], Gardariki [Gardariki], 2007, 223 p.

[4] E. L. Mara, D. Mara, Communicative Competence - Way of Relieving the Educative Processes, Procedia - Social and Behavioural Sciences 15 (2011) 1415-1418. DOI: https://doi.org/10.1016/j.sbspro.2011.03.304

[5] A.V. Karpov, Psychology of decision-making in professional activity [Psihologiya prinyatiya reshenij v professional'noj deyatel'nosti], Yurayt [YUrajt], 2019, 155 p. URL: https://www.biblioonline.ru/viewer/psihologiya-prinyatiya-resheniyv-professionalnoy-deyatelnosti-430909\#page/1

[6] C.E. Johnson, M.Z. Hackman. Leadership. A Communication Perspective. Seventh Edition. Waveland Press, 2018, 574 p.
[7] N.V. Matyash, T.A. Pavlova, Actual problems of theory and practice of modern psychology [Aktual'nye problemy teorii i praktiki sovremennoj psihologii], Direct-Media [Direkt-Media], 2020, 135 p. DOI: https://doi.org/10.23681/578501 URL: http://biblioclub.ru/index.php?page $=$ book\&id $=578$ 501.

[8] L.S. Vygotsky, Problems of the development of the psyche [Problemy razvitiya psihiki], Collected Works, Vol. 3 Pedagogy [Sobr. soch., T. 3. Pedagogika], 1983, 368 p.

[9] S.L. Rubinstein, Fundamentals of General Psychology [Osnovy obshchej psihologii], Piter, 2013, 713 p.

[10] B.F. Lomov, On the problem of decision-making [K voprosu o probleme prinyatiya reshenij], Questions of Cybernetics [Voprosy kibernetiki], Nauka, 1975, Issue 8.

[11] G.S. Filippov, Gender features of the style and process of managerial decision-making [Gendernye osobennosti stilya i processa prinyatiya upravlencheskih reshenij], Crimean Academic Bulletin [Krymskij akademicheskij vestnik] 19 (2021) 324-332.

[12] E.M. Klimova, Gender features of decisionmaking in managerial activity [Gendernye osobennosti prinyatiya resheniya v upravlencheskoj deyatel'nosti], Psychology. Historical and critical reviews and modern research [Psihologiya. Istoriko-kriticheskie obzory i sovremennye issledovaniya] 7(5) (2018) 52-61.

[13] J. Nilsson C. Lundmark, The effect of personal values and the roles on representational principles in natural resource management decision-making, Heliyon, Vol. 6, Issue 5, 2020. DOI: https://doi.org/10.1016/j.heliyon.2020.e04032

[14] H.A. Simon, Administrative Behaviour: A Study of Decision-Making Processes in Administrative Organisations, 4th Edition, Free Press, 1997, 370 p. URL:

https://books.google.ru/books?hl=en\&lr=\&id=_obn 42iD3mYC\&oi=fnd\&pg=PA1\&ots=vYoaBrigW\&sig=RxrdPbO5WGq0OiXEqoiYfMKx $\underline{\mathrm{wg} 4 \& \text { redir_esc }=\mathrm{y} \# \mathrm{v}=\text { onepage } \& \mathrm{q} \& \mathrm{f}=\text { false }}$

[15] S.I. Filippchenkova, F.V. Stroganova, The study of personal factors influencing managerial decisionmaking [Issledovanie lichnostnyh faktorov, vliyayushchih na prinyatie upravlencheskih reshenij], Bulletin of TvSTU. The series "Social Sciences and Humanities" [Vestnik TvGTU. Seriya «Nauki ob obshchestve i gumanitarnye nauki»] 1 (2016) 108-112. 